Jurnal MAKSIPRENEUR, Vol. V, No. 2, Juni 2016, hal. 46 - 56

\title{
PENGARUH BURNOUT TERHADAP KECERDASAN EMOSIONAL, SELF-EFFICACY, DAN KINERJA DOKTER MUDA DI RUMAH SAKIT dr. SOEBANDI
}

\author{
Raden Roro Lidia Imaniar (lidiaimaniar22@gmail.com) \\ R. Andi Sularso (sularso.andi60@gmail.com) \\ Universitas Jember
}

\begin{abstract}
The Effect Of Burnout On Emotional Intelligence, Self-Efficacy, And CoAssistant Performance In dr. Soebandi Hospital Jember.The purpose of the studi was to examine and explain (1) the effect of burnout on co-assistant performance; (2) the effect of burnout on emotional intelligence; (3) the effect of burnout on self-efficacy; (4) the effect of emotional intelligence on co-assistant performance; and (5) the effect of selfefficacy on co-assistant performance.The sampel of this study consisted of 94 coassistant in dr. Soebandi Hospital Jember. Sample was chosen based on porpusive random sampling technique. Questionnaire was the main instrument to collect data. Data was analyzed using descriptive analyses employing Partial Least Square (PLS).The findings in this study is (1) burnout has a significant and negative effect coassistant performance; (2) burnout has a significant and positive effect on emotional intelligence; (3) burnout has a non-significant and positive effect on self-efficacy; (4) emotional intelligence has a significant and positive effect on co-assistant performance; and (5) self-efficacy has a significant and positive effect on co-assistant performance.
\end{abstract}

Keywords: Burnout, Emotional Intelligence, Self-Efficacy, Co-Assistant Performance.

\section{PENDAHULUAN}

Mahasiswa pendidikan profesi fakultas kedokteran yang biasa disebut dokter muda atau ko-as adalah mahasiswa yang telah mendapatkan gelar sarjana kedokteran (S.Ked) dan menjalani proses belajar di tataran pelayanan kesehatan di rumah sakit, pusat kesehatan, klinik keluarga, serta unit pelayanan kesehatan lainnya. Setelah menyelesaikan fase ini mahasiswa berhak menyandang gelar dokter. Pendidikan klinik sebagai suatu proses belajar mengajar yang berpusat pada mahasiswa, yang terjadi dalam konteks perawatan pasien. Dalam tahap pendidikan klinik, selain mengaplikasi teori untuk pengembangan pengetahuan dan keterampilan, juga menerapkan unsur sikap dan etika dalam pelayanan pasien.

Suatu hal yang tidak dapat dipisahkan dalam kehidupan kerja dokter muda adalah burnout, mengingat tingginya mobilitas kerja dalam melayani pasien. Burnout merupakan tipe khusus ketegangan yang mencerminkan sebuah kepercayaan bahwa beberapa sumber untuk menanggulangi kondisi yang menekan akan menimbulkan seseorang mengalami keputus-asaan, keletihan dan kelelahan kognitif (Lee dan Ashforth dalam Alam, 2007). Maslach (1997)mengatakan burnout merupakan sindrome psikologis yang terdiri dari tiga dimensi, yaitu (i) kelelahan emosional, (ii) depersonalisasi, (iii) low personal accomplisment. Dijelaskan bahwa pekerjaan yang 
berorientasi melayani orang lain dapat membentuk hubungan yang asimetrik antara pemberi dan penerima layanan. Para peneliti mengkaitkan burnout dengan beragam masalah kesehatan mental dan fisik, keburukan rumah tangga dan hubngan sosial, meningkatnya pergantian dan ketidakhadiran.

Mengatasi burnout bukanlah hal yang mudah bagi seseorang, terkecuali bagi mereka yang memiliki self-efficacy, seperti ungkapan Baron \& Byrne (1991) selfefficacy merupakan evaluasi seseorang mengenai kemampuan atau kompetensi dirinya untuk dapat melakukan suatu tugas guna mencapai tujuan, dan mengatasi hambatan yang dialaminya. Demikian pula, self-efficacy akan dapat memengaruhi usaha dan ketahanan seseorang atau individu dalam menghadapi kesulitan. Individu dengan selfefficacy tinggi melihat suatu tugas yang sulit sebagai suatu tantangan untuk dihadapi (Bandura, 1997). Penelitian tentang pengaruh self-efficacy terhadap burnout dilakukan oleh peneliti sebelumnya, seperti Skaalvik \& Skaalvik (2010) dan Schaufeli \& Salanova (2007), menunjukkan bahwa self-efficacy berpengaruh signifikan positip terhadap burnout, dan menganggap kelelahan emosional dan depersonalisasi sebagai unsur sentral dari burnout. Sedangkan hasil penelitian yang dilakukan oleh Maharani (2011), menunjukkan bahwa self-efficacy berpengaruh signifikan negatip terhadap burnout.

Kinerja dokter muda tidak hanya dilihat dari kemampuan kerja yang sempurna, tetapi juga kemampuan menguasai dan mengelola diri sendiri serta kemampuan dalam membina hubungan dengan orang lain. Kemampuan tersebut oleh Goleman disebut dengan emotional intelligence atau kecerdasan emosi. Goleman (2002) mengatakan bahwa kecerdasan emosi menyumbang $80 \%$ dari faktor penentu kesuksesan seseorang, sedangkan $20 \%$ yang lain ditentukan oleh IQ (Intelligence Quotient). Penelitian empirik mengenai kecerdasan emosi yang mendasaripenelitian yang dilakukan Ani Muttaqiyatun(2010) menunjukkan hasil bahwa kecerdasan emosional berhubungan positif dengan performance atau kinerja. Hasil ini sesuai dengan hasil penelitian yang telah dilakukan sebelumnya bahwa kecerdasan emosional dokter muda dapat memprediksi hasil yang dihubungkan dengan pekerjaan, seperti kinerja.Penelitian oleh Alvis Muryo Dewanto dan Siti Nurhayati (2013). yang mengindikasikan kecerdasan emosional meningkatkan sikap kerja positif, perilaku rendah hati dan hasil kerja, dan memoderasi pengaruh konflik keluarga-pekerjaan terhadap komitmen karir, tetapi tidak berpengaruh pada kinerja. Penelitian tentang pengaruh kecerdasan emosional terhadap kinerja individu telah dilakukan oleh Jorfi, Jorfi \& Moghadam (2010); dan Shahosseini, Silong \& Ismail (2012) kecerdasan emosional berpengaruh signifikan positip terhadap kinerja individu. Penelitian Vivin Maharani (2013) burnout dan emotional intelligenceberpengaruhsignifikan terhadap prestasi kerja pegawai. Sedangkan Devi (2011), menemukan bahwa burnout dengan indikator kelelahan fisik, kelelahan emosional, depersonalisasi berpengaruh signifikan negatip terhadap seluruh indikator pada kecerdasan emosional.

\section{RUMUSAN MASALAH DAN TUJUAN PENELITIAN}

Berdasarkan latar belakang, maka rumusan masalah dalam penelitian adalah sebagai berikut(1) apakah burnout berpengaruh terhadap kinerja dokter muda di RS. dr. Soebandi Jember ?(2) apakah burnout berpengaruh terhadap kecerdasan emosional dokter muda di RS. dr. Soebandi Jember ? (3) apakah burnout berpengaruh terhadap self-efficacy dokter muda di RS dr. Soebandi Jember ? (4) apakah kecerdasan emosional berpengaruh terhadap kinerja dokter muda di RS. dr. Soebandi Jember ? 
(5) apakah self-efficacyberpengaruh terhadap kinerja dokter muda di RS. dr. Soebandi Jember?

Sedang tujuan penelitian adalah untuk menganalisis: (1).pengaruh burnout terhadap kinerja dokter muda di RS. dr. Soebandi Jember (2) pengaruhburnout terhadap kecerdasan emosional dokter muda di RS. dr. Soebandi Jember (3) pengaruh burnout terhadap self-efficacy dokter muda di RS dr. Soebandi Jember (4) pengaruh kecerdasan emosional terhadap kinerja dokter muda di RS. dr. Soebandi Jember (5) pengaruh self-efficacy terhadap kinerja dokter muda di RS. dr. Soebandi Jember .

\section{TINJAUAN PUSTAKA}

\section{A. Kecerdasan Emosional}

Kecerdasan emosional adalah kemamapuan memantau dan mengendalikan perasaan sendiri dan orang lain serta menggunakan perasaan-perasaan tersebut untuk memandu pikiran dan tindakan, sehingga emosional intelligency sangat diperlukan untuk sukses dalam bekerja dan menghasilkan kinerja yang menonjol dalam pekerjaan (Sam'ani, 2008). Sehingga orang yang mampu memiliki emotional intelligency akan mampu menghadapi tantangan dan menjadikan seseorang yang penuh tanggung jawab, produktif, optimis dalam menghadapi dan menyelesaikan masalah, hal-hal tersebut sangat dibutuhkan dalam hubungan kerja.Menurut Patton (2011) EQ artinya sederhana, menggunakan emosi secara efektif untuk mencapai tujuan, membangun hubungan produktif, dan meraih keberhasilan di tempat kerja. EQ adalah penjembatan kesenjangan antara apa yang kita ketahui dan lakukan. Semakin tinggi EQ, semakin trampil melakukan apa yang kita ketahui benar. Goleman (2002) mengatakan bahwa kecerdasan emosional adalah kemampuan untuk merasakan, memahami dan secara efektif menerapkan daya dan kepekaan emosi, sebagai sumber energi, informasi, emosi dan pengaruh yang manusiawi.

\section{B. Self-efficacy}

Bandura (1997) mendefinisikan self-efficacy sebagai keyakinan individu tentang "kemampuan mereka untuk menghasilkan tingkat kinerja yang ditunjuk mempunyai pengaruh atas peristiwa yang memengaruhi kehidupan mereka. Keyakinan Self-effecacy menentukan bagaimana orang merasa, berpikir, memotivasi diri dan berperilaku". Ada tiga sumber utama dari self-efficacy. Faktor penentu yang paling kuat dari self-efficacy adalah penguasaan diri, diikuti dengan peran modeling, dan kemudian persuasi verbal, namun Lev dan Koslowsky (2009), memperkenalkan kondisi fisiologis (subjektif pengaruh personal) sebagai sumber lain, yang memengaruhi penilaian dari self-efficacy dengan individu merasa takut, cemas atau tegang dan mereka menilai diri mereka kurang mampu untuk mencapai tugas yang diberikan. Hal ini kebanyakan mempengaruhi petugas dalam rantai pasokan karena mereka mungkin anggap rendah diberdayakan untuk menghasilkan yang diinginkan. Ivancevich et al., (2006) menjelaskan bahwa self-efficacy berhubungan dengan keyakinan pribadi mengenai kompetensi dan kemampuan diri. Secara spesifik, hal tersebut merujuk pada keyakinan seseorang terhadap kemampuan untuk menyelesaikan suatu tugas secara berhasil. Keyakinan berkenaan dengan self-efficacy adalah sesuatu yang dipelajari. Faktor yang paling penting dalam pengembangan self-efficacy adalah pengalaman masa lalu. Jika selama suatu periode individu mengusahakan suatu tugas dan berhasil dalam kinerja, maka individu akan lebih mungkin mengembangkan rasa percaya diri dan keyakinan yang meningkat dalam kemampuan individu untuk melaksanakan sesuatu dengan baik. 


\section{Burnout}

Burnout merupakan istilah psikologis yang digunakan untuk menunjukkan keadaan kelelahan kerja. Istilah burnout pertama kali diperkenalkan oleh Bradley pada tahun 1969, namun tokoh yang dianggap sebagai penemu dan penggagas istilah burnout adalah Herbert Freudenberger, dalam bukunya, Burnout: The High Cost of High Achievement pada tahun 1974, memberikan ilustrasi tentang apa yang dirasakan seseorang yang mengalami sindrom tersebut seperti gedung yang terbakar habis (burned-out). Suatu gedung yang pada mulanya berdiri tegak dan megah dengan berbagai aktivitas di dalamnya, setelah terbakar yang tampak hanyalah kerangka luarnya saja. Demikian pula dengan seseorang yang terkena kelelahan kerja, dari luar segalanya masih tampak utuh, namun di dalamnya kosong dan penuh masalah (seperti gedung yang terbakar tadi). Sejak itu pula terminologi burnout berkembang menjadi pengertian luas dan dipakai untuk memahami phenomena kejiwaan seseorang. Burnout dapat diartikan sebagai kehabisan tenaga (Babakus, et al.,2009).

Pines \& Guendlman (1995) mendefinisikan bahwa orang yang mengalami tekanan pekerjaan terus menerus akan mengalami depersonalization yang meru-pakan tendensi kemanusiaan terhadap sesama yang merupakan pengembangan sikap sinis mengenai karir dan kinerja diri sendiri. Bhanugopan \& Alan (2006) mengatakan para pekerja yang terkena kelelahan kerja (burnout) mengalami kelelahan mental, kehilangan komitmen, kelelahan emosional, dan juga mengalami penurunan motivasi seiring dengan berjalannya waktu.

Maslach \& Jackson (1981) mendeskripsikan burnout sebagai gabungan dari tiga tendensi psikis, antara lain; kelelahan emosional/emotionalexhaustion, sikap tidak perduli terhadap karir dan diri sendiri atau depersonalization, serta penurunan pencapaian individu/personalaccomplishment. Baron \& Greenberg (2008) mengatakan burnout memiliki empat indikator yang terdiri atas kelelahan fisik atau physical exhaustion, kelelahan emosional atau emotional exhaustion, dan kelelahan mental atau mental exhaustion, serta rendahnya penghargaan diri atau low of personal accomplishment.

\section{Kinerja}

Kinerja atau performance merupakan target atau hasil yang harus dicapai, seperti merefleksikan laba yang dihasilkan atau pendapatan bisnis tahun lalu. Dalam perusahaan yang profesional, kinerja didefinisikan berdasarkan sudut pandang penciptaan nilai yang berhubungan dengan rantai input, process, dan output (Kaiser and Ringstetter, 2011). Juga dijelaskan bahwa kinerja seseorang karyawan akan sangat dipengaruhi oleh cara individu tersebut merespons kondisi yang memengaruhi proses kerjanya. Mathis and Jackson (2009) memberikan definisi kinerja sebagai apa yang dilakukan atau tidak dilakukan oleh karyawan.Kinerja karyawan yang secara umum meliputi elemen sebagai berikut (Mathis and Jackson, 2009): (1) kuantitas dan hasil; (2) kualitas dan hasil; (3) ketepatan waktu dari hasil; (4) kehadiran; (5) kemampuan bekerja sama.

\section{E. Hipotesis}

Hipotesis yang dikemukakan dalam penelitian ini adalah: (1). Ada pengaruh burnout terhadap kinerja dokter muda di RS. dr. Soebandi Jember.(2) Ada pengaruh burnout terhadap kecerdasan emosional dokter muda di RS. dr. Soebandi Jember. (3) Ada pengaruh burnout terhadap self-efficacy dokter muda di RS dr. Soebandi Jember 
(4) Ada pengaruh kecerdasan emosional terhadap kinerja dokter muda di RS. dr. Soebandi Jember (5) Ada pengaruh self-efficacy terhadap kinerja dokter muda di RS. dr. Soebandi Jember .

\section{METODE PENELITIAN}

Penelitian ini adalah penelitian survey dengan mengambil sampel dari populasi dengan menggunakan daftar pernyataan sebagai alat pengumpul data. Berdasarkan tujuan penelitian, maka penelitian ini termasuk jenis explanatory research. Penelitian ini disebut sebagai penelitian pengujian hipotesis atau testing research. Data dikumpulkan bersifat cross sectional diperoleh dari responden dalam merespon itemitem berkaitan dengan variabel dalam bentuk daftar pernyataan.

Populasi diartikan sebagai wilayah generalisasi yang terdiri dari obyek atau subyekyangmempunyai karakteristik tertentu dan mempunyai kesempatan yang sama untuk dipilih menjadi anggota sampel. Populasi penelitian adalah dokter muda di RS dr. Soebandi Jember yang berjumlah 94 orang.Unit sampel dalam penelitian ini adalah sama dengan unit analisisnya yaitu dokter muda di RS dr. Soebandi Jember. Sampel penelitian ini menggunakan semua individu dalam populasi sebagai responden, sehingga jumlah sampel sama dengan jumlah populasi yang berjumlah 94 orang

Pengumpulan data dilakukan melalui beberapa cara meliputi: (1) Survey, memberi kuisioner (daftar pernyataan) kepada responden dan mereka hanya menjawab sesuai dengan pilihan jawaban dalam daftar pernyataan tersebut. Responden ditemui pada waktu melakukan ko-as (co-assistant) di RS. dr. Soebandi Jember; (2) Wawancara, dimaksudkan mendapatkan informasi tambahan terkait permasalahan dalam memberikan layanan kepada pasien.

Metode analisis data yang digunakan untuk penelitian ini: (1) analisis Partial Least Square (PLS). Alasan penggunaan Partial Least Square (PLS) karena; dimungkinkan melakukan pemodelan persamaan structural dengan ukuran sampel dapat disesuaikan dan tidak membutuhkan asumsi normal multivariate, merupakan metode analisis powerful karena dapat diterapkan semua skala data, selain dapat digunakan sebagai konfirmasi teori juga digunakan membangun hubungan belum ada landasan teorinya atau pengujian variabel independen dilambangkan dengan $\mathrm{X}$, variabel dependen dengan $\mathrm{Y}$, dan variabel mediasi diberi lambang $\mathrm{M}$.

\section{HASIL PENELITIAN DAN PEMBAHASAN}

Pengujian hipotesis di dalam Analisis PLS menggunakan uji t dengan mengaplikasikan metode resampling bootstrap. Hasil pengujian hipotesis pengaruh langsung ditampilkan pada tabel 5.1 berikut. 
Tabel 1

Hasil Pengujian Hipotesis Pengaruh Langsung

\begin{tabular}{|c|l|l|c|c|c|}
\hline No & \multicolumn{2}{|c|}{ Hubungan antar Variabel } & $\begin{array}{c}\text { Koefisien } \\
\text { Jalur }\end{array}$ & p-value & Keterangan \\
\hline 1 & Burnout $\left(\mathrm{X}_{1}\right)$ & Kinerja $\left(\mathrm{Y}_{3}\right)$ & -0.116212 & 0.0000 & Signifikan \\
\hline 2 & Burnout $\left(\mathrm{X}_{1}\right)$ & $\begin{array}{l}\text { Kecerdasan } \\
\text { Emosional }\left(\mathrm{Y}_{1}\right)\end{array}$ & 0.711377 & 0.0000 & Signifikan \\
\hline 3 & Burnout $\left(\mathrm{X}_{1}\right)$ & $\begin{array}{l}\text { Sel-efficacy } \\
\left(\mathrm{Y}_{2}\right)\end{array}$ & 0.118101 & 0.0915 & $\begin{array}{c}\text { Tidak } \\
\text { Signifikan }\end{array}$ \\
\hline 4 & $\begin{array}{l}\text { Kecerdasan Emosional } \\
\text { (Y) }\end{array}$ & Kinerja $\left(\mathrm{Y}_{3}\right)$ & 0.672039 & 0.0000 & Signifikan \\
\hline 5 & Sel-efficacy $\left(\mathrm{Y}_{2}\right)$ & Kinerja $\left(\mathrm{Y}_{3}\right)$ & 0.273222 & 0.0001 & Signifikan \\
\hline
\end{tabular}

Keterangan : signifikan pada $\alpha 5 \%$

Sumber : Hasil analisis

Hasil pengujian tersebut juga disajikan dalam bentuk gambar berupa diagram jalur sebagai berikut.

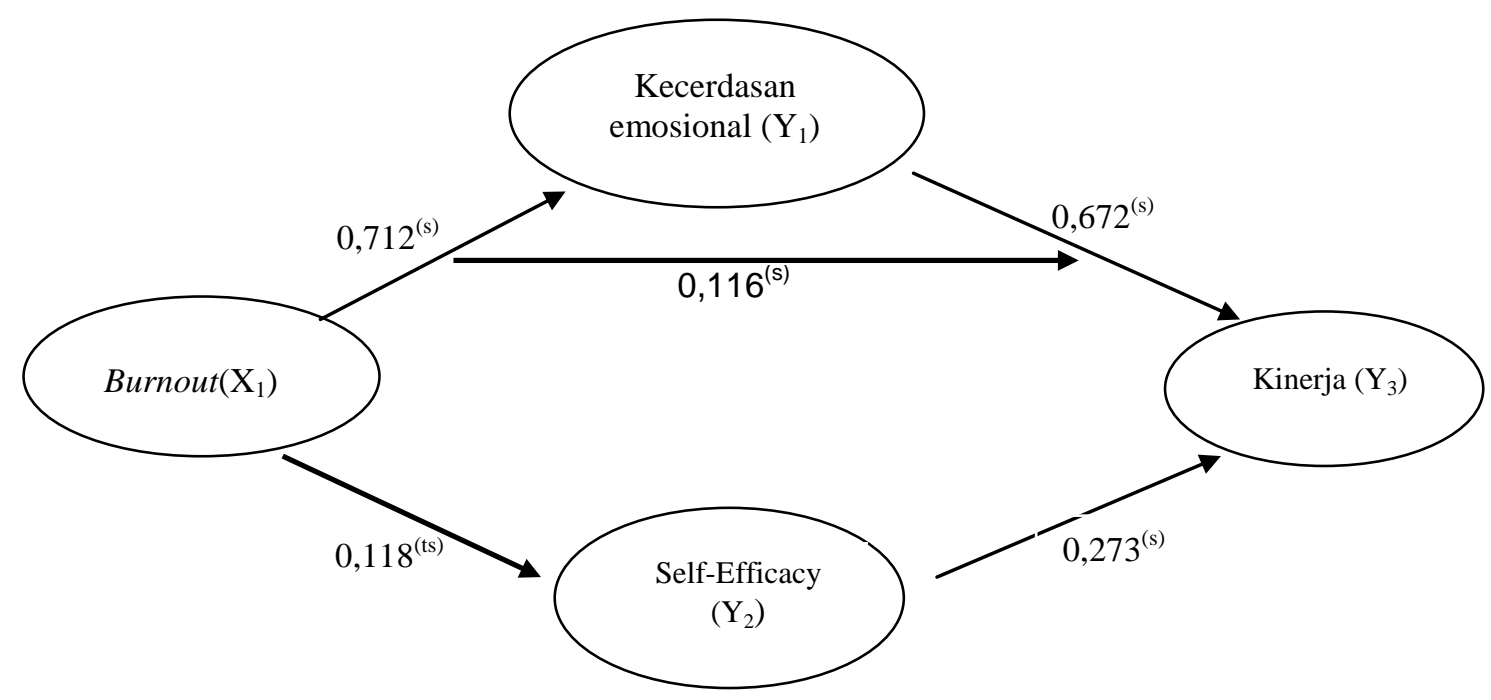

Sumber: Hasil analisis

Gambar 1

Diagram Jalur

Pengujian variabel kepuasan dan sikap loyal sebagai variabel mediasi dilakukan dengan uji Sobel. Proses perhitungan dilakukan dengan software ADSTAT, hasilnya secara lengkap dapat dilihat pada table 2 .

Tabel 2

Hasil Pengujian Variabel Mediasi: Koefisien Pengaruh Tidak Langsung dengan Uji Sobel

\begin{tabular}{|c|c|c|c|c|c|c|}
\hline No & $\begin{array}{c}\text { Variabel } \\
\text { Independen }\end{array}$ & $\begin{array}{r}\text { Variabel } \\
\text { Mediasi }\end{array}$ & $\begin{array}{c}\text { Variabel } \\
\text { Dependen }\end{array}$ & Koefisien & p-value & Keterangan \\
\hline 1 & Burnout $\left(\mathrm{X}_{1}\right)$ & $\begin{array}{l}\text { Kecerdasan } \\
\text { Emosional }\end{array}$ & Kinerja $\left(\mathrm{Y}_{3}\right)$ & 0.2433 & $0.000 *$ & Mediasi \\
\hline
\end{tabular}




\begin{tabular}{|c|l|l|l|l|l|c|}
\hline & & $\left(\mathrm{Y}_{1}\right)$ & & & & \\
\hline 2 & Burnout $\left(\mathrm{X}_{1}\right)$ & $\begin{array}{l}\text { Self- } \\
\text { efficacy }\left(\mathrm{Y}_{2}\right)\end{array}$ & Kinerja $\left(\mathrm{Y}_{3}\right)$ & 0.0200 & $0.151^{\text {ts }}$ & $\begin{array}{c}\text { Bukan } \\
\text { Mediasi }\end{array}$ \\
\hline 3 & Kepuasan $\left(\mathrm{Y}_{1}\right)$ & $\begin{array}{l}\text { Self- } \\
\text { efficacy }\left(\mathrm{Y}_{2}\right)\end{array}$ & Kinerja $\left(\mathrm{Y}_{3}\right)$ & 0.1732 & $0.010^{*}$ & Mediasi \\
\hline
\end{tabular}

Keterangan : $*$ = signifikan $;$ ts $=$ tidak signifikan

Sumber : Hasil Analisis

Berdasarkan Tabel1 dan 2. serta Gambar 1 diperoleh hasil analisis penelitian dan pembahasan sebagai berikut.

1. Hasil analisis model struktural dengan metode jalur, memperlihatkan adanya pengaruh signifikan dan negatif antara burnout dan kinerja dokter muda. Berdasarkan hasil analisis pada tabel 5.1, yaitu nilai koefisien jalur sebesar - 0,116 dengan arah negatif, dengan p-value 0,000 ( signifikan). Hal tersebut menggambarkan semakin tinggi tingkat burnout yang dialami dokter muda, maka akan semakin rendah tingkat kinerja individu yang dihasilkan. Demikian pula sebaliknya, apabila tingkat burnout yang dialami dokter muda semakin rendah, maka semakin tinggi tingkat kinerja dokter muda yang dihasilkannya. Temuan ini mengkonfirmasi dan memperluas hasil penelitian sebelumnya yang dilakukan oleh Babakus et al (2009); Ybema, Smulders \& Bongers (2010); Gorji (2011); dan Gorji \& Vaziri (2011)Kounenou \& Demerouti (2012); Ybema, Smulders \& Bongers (2010); dan Chen \& Kao (2012). Namun penelitian ini berbeda dengan penelitian yang dilakukan oleh Idrus (2016), bahwa burnout berpengaruh tidak signifikan terhadap kinerja pramuwisata di Provinsi Nusa Tenggara Barat.

2. Hasil penelitian menemukan bahwa pengaruh burnout terhadap kecerdasan emosional signifikan. Berdasarkan hasil analisis pada table 5.1, yaitu nilai koefisien jalur sebesar 0,712 dengan arah positip, dengan p-value 0,000 (signifikan). Hal ini menunjukkan bahwa, jika semain tinggi tingkat burnout yang dimiliki dokter muda, maka akan semakin tinggi tingkat kecerdasan emosional dokter muda. Sebaliknya, jika burnout yang dimiliki oleh dokter muda semakin rendah, maka akan dapat mengakibatkan semakin rendah pula kecerdasan emosional dokter muda. Hal ini mengindikasikan bahwa burnout terbukti berpangaruh signifikan secara nyata, karena didukung fakta lapangan, sehingga dapat mengurangi kecerdasan emosional. Temuan ini sama dengan teori Banughopan (2006) mengenai para pekerja yang terkena burnout akan mengalami kelelahan mental, kelelahan emosional, kehilangan komitmen, dan mengalami penurunan motivasi diri seiring dengan berjalannya waktu. Temuan penelitian ini mendukung hasil penelitian sebelumnya yang telah dilakukan oleh Alam (2010); Devi (2011); Khanifar, et al (2012); Thomas, et. al (2012); dan Idrus (2016).

3. Hasil penelitian burnout terhadap self-efficacy berpengaruh tidak signifikan. Berdasarkan hasil analisis pada table 5.1, yaitu nilai koefisien jalur sebesar 0,118 dengan p-value 0,09 (tidak Signifikan) dengan arah positip Hal ini mengindikasikan bahwa burnout secara nyata mempunyai peranan kurang penting terhadap selfefficacy. Bila dilihat dari hasil pengujian variabel mediasi dengan uji Sobel dengan p-value 0,151 (tidak signifikan), maka self-efficacy bukan mediasi dari burnout terhadap kinerja (tabel 5.2). Sehingga temuan penelitian ini berbeda dengan teori Baron \& Byrne (1991) tentang self-efficacy yang merupakan evaluasi sesorang mengenai kemampuan atau kompetensi dirinya untuk melakukan tugas, mencapai tujuan, dan mengatasi hambatan (burnout) yang dialaminya. Temuan ini berbeda 
juga dengan temuan penelitian yang telah dilakukan sebelumnya oleh Skaalvik, \& Skaalvik (2010); Maharani (2011); Aftab, Asghar \& Roqia (2012); dan Idrus (2016).

4. Hasil analisis pada model struktural dengan analisis jalur, memperlihatkan bahwa kecerdasan emosional berpengaruh positip dan signifikan terhadap kinerja dokter muda, sesuai hasil analisis pada table 5.1 dengan nilai koefisien jalur sebesar 0,672 pada tingkat kepercayaan 95\% dengan p-value 0,000 ( signifikan). Hal ini menunjukkan bahwa, jika semain tinggi tingkat kecerdasan emosional yang dimiliki dokter muda, maka akan semakin tinggi tingkat kinerja yang dihasilkan oleh dokter muda. Sebaliknya, jika kecerdasan emosional yang dimiliki oleh dokter muda semakin rendah, maka akan dapat mengakibatkan semakin rendah pula tingkat kinerja dokter muda. Hasil penelitian ini mengkonfirmasi dan memperluas temuan dari penelitian yang dilakukan Yadav (2011) tentang kecerdasan emosional mempunyai pengaruh positip dan signifikan terhadap kinerja. Temuan dalam penelitian Yadav (2011) tersebut hasilnya sama dengan temuan penelitian yang dilakukan oleh Shahhosseini, et al (2012); dan Idrus (2016).

5. Hasil analisis memperlihatkan bahwa self-efficacy berpengaruh positip dan signifikan terhadap kinerja dokter muda, berdasarkan hasil analisis pada tabel 5.1, yaitu nilai koefisien jalur sebesar 0,273 dengan arah positip pada tingkat kepercayaan $95 \%$ dengan p-value 0,0001 ( signifikan). Hal ini menunjukkan bahwa semakin tinggi tingkat self-efficacy yang dimiliki oleh dokter muda, maka akan semakin tinggi tingkat kinerja yang dihasilkan oleh dokter muda. Demikian pula sebaliknya, jika semakin rendah tingkat self-efficacy yang dimilikinya, maka akan semakin rendah pula tingkat kinerja yang dihasilkan oleh dokter muda. Dengan demikian makna yang dapat ditarik dari temuan ini adalah self-efficacy dan kinerja dokter muda merupakan dua hal yang sangat penting, mempunyai pengaruh satu dengan lainnya. Hasil temuan ini mengkonfirmasi dan memperluas teori Bandura (1986), tentang self-efficacy merupakan penilaian atau persepsi subjektif dari individu terhadap kemampuan dirinya dalam mengorganisir, dan memutuskan tindakan yang dibutuhkan untuk mencapai kinerja (performance) yang diinginkan. Demikian pula hasil penelitian ini mengkonfirmasi dan memperluas hasil penelitian sebelumnya yang telah dilakukan oleh Khurshid, et al (2012). Temuan dalam penelitian mereka tersebut, disimpulkan bahwa terdapat pengaruh positip, sifnifikan antara self-efficacy, dan kinerja guru di sekolah menenngah Rawalpindi dan Islamabad di India. Selain itu, mereka juga menemukan guru perempuan dan guru yang berpengalaman mengajar lebih lama, serta guru yang memiliki jenjang pendidikan lebih tinggi, akan memiliki self-efficacy lebih tinggi.

\section{KESIMPULAN}

Hasil penelitian ini menemukan bahwa burnout berpengaruh signifikan negatif terhadap kinerja dokter muda, burnout berpengaruh signifikan terhadap kecerdasan emosional, burnout berpengaruh tidak signifikan terhadap self-efficacy, kecerdasan emosional berpengaruh signifikan terhadap kinerja, dan self-efficacy berpengaruh signifikan terhadap kinerja. 


\section{DAFTAR PUSTAKA}

Alam, R. 2007. Empowerment hubungannya dengan burnout paramedis rumah sakit rujukan.Disertasi. Tidak dipublikasikan.

Alam, Rosalina, 2010, "Pengaruh PemberdayaanTerhadap Kelelahan Kerja dan Kecerdasan Emosional Perawat dan Bidan Pada Rumah Sakit Umum Rujukan di Sulawesi Selatan" Jurnal EKUITAS,pp. 187-209

Aftab.Noman., Shah.Asghar Ali., \& Mehmood, Roqia. 2012. "Relationship of Self Efficacy and Burnout Among Physicians". Academic Research International. Vo.2. No.2, pp.539-548.

Alvis Muryo Dewanto, Siti Nurhayati, 2013, Pengaruh Kecerdasan Emosional Dan Kecerdasan Spiritual Terhadap Sikap Etis Dan Prestasi Mahasiswa Akuntansi (Studi Pada Perguruan Tinggi Dota Pekalongan),http://journal.unikal.ac.id/index.php/lppm/article/viewFile/139/76

Ani Muttaqiyathun, Hubungan Emotional Quotient, Intelectual Quotient Dan Spiritual Quotient Dengan Entrepreneur's Performance, Jurnal Manajemen Bisnis, Vol. 2 N0.3, Maret 2010., Hal 221-234.

Babakus.Emin., Yavas.Ugur., \& Ashill,Nikolas.J. 2009. "The role of customer orientation as a moderator of the job demandebumouteperformance relationship: a surfacelevel trait perspective". Journal of Retailing. Vol.85, pp.480-492.

Bandura, A. 1997. Self-Efficacy:The Exercise of Control, W.H. Freeman, New York, NY.

Bandura, Albert, 1986. Social Foundation of Thought and Action: A Social Cognitive Theory. NJ: Prentice -Hall. Englewood Cliffs.

Baron,Robert, A., \& Byrne.D. 1991. Social Psychology Understanding Human Interaction. Allyn \& Bacon. Boston.

Baron, obert, A., \& Greenberg.J. 2008. Behaviour in organization: understanding and managing the human side of work. 9th ed. Prentice Hall. USA.

Bhanugopan.Ramadu., \& Alan, Fish. 2006. "An Empirical Investigation of Job Burnout among Expatriates". Personal Review. Vol.35. No.4, pp.449-468.

Chen, Ching-Fu., \& Kao, Ya-Ling., 2012. "Investigating The Antecedents and Concequences of Burnout and Isolation Among Flight Attendants"Tourism Management. Vol.3, pp.863-874

Devi, Minakshi, 2011, Burnout In Relation to Emotional Intelligence of Regular and Special School Teachers. Indian Streams Research Journal. Vol 1. No.6 pp.48-53

Golemen, Boyatzis, McKee. 2002. Primal Leadership: Learning To Lead With Emotional Intelligence, Printed in the United States of America.

Gorji, Mohammadbagher., 2011. "The Effect of Job Burnout Dimension on Employees Performance". International Journal of Social Science and Humanit, 1. No.4, pp.243-224

Gorji, Mohammadbagher., \& Vaziri., S 2011. "The Survey Job Burnout Status and Its Relation With The Performance of The Employees (Case Study: Bank)". International Conference on Innovation, Management and Service Vol. 14, pp.219-224

Idrus, Syech, 2016, Pengaruh Pemberdayaan Psikologis Terhadap self-Efficacy, Burnout, Kecerdasan Emosional, Kepuasan kerja Dan Kinerja Individu: Studi Terhadap Pramuwisata Di Provinsi Nusa Tenggara Barat, Disertasi Fakultas Ilmu Administrasi Universitas Brawijaya, Malang. 
lvancevich,J ohn M., Robert KonopaskeM, ichaelT . Matteson.2 006. Perilaku dan Manajemen Organisasi Edisi 7 . Jilid1 . Jakarta:Erlangga.

Jorfi, Hassan., Jorfi, Saeid., \& Moghadam, Korahi. 2010. "Impact of Emotional Intelligence on Performance of Employees" Postmodern Openings. Vol 1. No.4, pp.63-74

Kaiser, Stephan dan Max Josef Ringlstetter 2011. Strategic Management of Professional Service Firms: Theory and Practice Heidelberg, Berlin. SpringerVerlag

Khanifar, H., Maleki,H., Nazari, K., \& Emami, M., 2012. "The Study of The Relation Between Emotional Intelligence and Burnout of Staff' (Case Study of Staff at State Universities in India) Interdisciplinary Journal of Contemporary Research in Business, Vol. 3. No. 10, pp.204-223

Kounenou, G., \& Demerouti' 2012. "Job Burnout and Employees Performance" Advance Research in Economic and Management Sciences . Vol.2.,pp.35-42

Khurshid, Fauzia., Qasmi,Farah Naz., \& Ashraf, Nadia. 2012. "The Relationship Between Teachers Self-Efficacy and Their Perceived Job Performance" Interdisciplinary Journal of Contemporary Research in Business, Vol. 3. No. 10, pp.204-223

Lev, S. \& Koslowsky M, . 2009. Moderating the collective and self-efficacy relationship. Journal of Educato nal Administration 4,7 (4), 452-462.

Maharani.Diah Restuning. 2011. "Pengaruh Self Efficacy terhadap Burnout pada Guru di Kota Bogor". Jurnal Psikologi Universitas Gajahmada. Vol.1, pp.1-10.

Maslach.Christina., \& Jackson,Susan.E. 1981. "The measurement of experien-ced burnout". Journal Occupational Behavior. Vol.2,pp.99-113.

Mathis, Robert L. dan Jhon H. Jackson. 2009. Manajemen Sumber Daya Manusia. Jakarta: Salemba Empat.

Patton, P. 2011. EQ Karir Sukses. Penerjemah: Zaini Dahlan. Pustaka Delaprata, Jakarta.

Pines,Ayala, \& Guendlman.Sylvia. 1995. Exploring the Relevance of Burnout to Mexican Blue Collar Woman. Journal of Vovational Behavior. Vo.47,pp. 1-20.

Sam'ani, Penerapan Emotional Spiritual Quotient (ESQ) Untuk Meningkatkan Kinerja Karyawan, Jurnal Pengembangan Humaniora, Vol 8 No.1, April 2008.

Shahhosseini, Mohammad., Silong, Abu Daud., Ismail, Ismi Arif., \& Uli, Jegak., 2012. "The Role of Emotional Intelligence on Job Performance". International Journal of Business and Social Science. Vol.3. No.21, pp.241-246.

Skaalvik, E. M., \& Skaalvik, S. 2010. "Teacher self-efficacy and teacher burnout : A study of relations". Teaching and Teacher Education. Vol. 26. No. 1. Pp. 1059 1069.

Thomas, Nur Sakinah., Mousavy, Seyedenhhava., Mukundan, Jayakaran., \& Nimehchisalem, Vahid., 2012. "The Relationship Between Burnout and Trait Emotional Intelligence Among Secondary School Teachers in Malaysia" International Journal of Applied Linguistics \& English Literature. 1. No.4, pp 1523

Vivin Maharani, 2013, Pengaruh Burnout Dan Kecerdasan Emosional Terhadap Kinerja Pegawai PT Bank Mega Syari'ah Cabang Malang, Jurusan Manajemen Fakultas Ekonomi UIN Maulana Malik Ibrahim Malang.

Ybema, J.F.,Smulders, P.G.W., Bongers, PM., 2010 "Antecendents and Consequences of Employee Absenteeism : a Longitudinal Perspective on the Role of Job 
Satisfaction and Burnout". European Journal of Work and Organizational Psychology. Vol. 19, pp.102-124

Yadav, Nidhi. 2011 "Emotional Intelligence and its Effects on Job Performance : A Comparative Studi On life Insurance Sales Professionals". International Journal Of Service Industry Management. Vol. 17, pp.258-270 